\title{
The Acquisition of Ethical Competence in Basic Education and the Present State of Ethics Education
}

\author{
Emi Yoshioka*, Sayuri Kaneko \\ Nagano College of Nursing, Komagane City, Japan \\ Email: ^eyoshioka@nagano-nurs.ac.jp, kanekosa@nagano-nurs.ac.jp
}

How to cite this paper: Yoshioka, E. and Kaneko, S. (2019) The Acquisition of Ethical Competence in Basic Education and the Present State of Ethics Education. Open Journal of Nursing, 9, 676-686. https://doi.org/10.4236/ojn.2019.97052

Received: June 19, 2019

Accepted: July 20, 2019

Published: July 23, 2019

Copyright (อ 2019 by author(s) and Scientific Research Publishing Inc. This work is licensed under the Creative Commons Attribution International License (CC BY 4.0).

http://creativecommons.org/licenses/by/4.0/

\section{(c) (i) Open Access}

\begin{abstract}
The aim of this study was to reveal the level of ethical competence acquired through basic nursing education, to report on the present state of ethics education, and to consider future directions for ethics education. The medical databases ICHUSHI, MEDLINE, and CINAHL were searched using the search terms "nursing ethics," "nursing practice," "ethics education," and "nursing students." Of the total results, 25 research articles (original papers, research reports, practical reports, documents) were used for this study. Ethical competence covered in basic nursing education corresponded to points 1 - 11 of the Code of Ethics, and the competencies acquired included cognizance and judgement. Ethics education included methods such as case studies in Japan and blended learning in other countries. At present, ethical competence education does not comprehensively cover the Code of Ethics, and the judgement level of competence is not acquired during basic nursing education. It is thus necessary henceforth to progressively put an educational program in place to develop ethics education that persists from basic nursing education through to continuing nursing education.
\end{abstract}

\section{Keywords}

Nursing Ethics, Ethics Education, Ethical Competence, Nursing Students

\section{Introduction}

Nurses are required to respond to ethical problems every day since they work in a healthcare environment characterized by rapid medical progress and diversifying ethical problems. Thus, organizations around the world, such as the International Council of Nurses (ICN), are creating codes of ethics to serve as behavioral guidelines for nurses. Each country revises their own code of ethics based 
on healthcare and societal changes, or on revisions to the code of ethics for ICN nurses.

The ICN Code of Ethics for Nurses was created in 1953. It is a set of behavioral guidelines for nurses based on social values and needs; therefore, nurses must understand, master, and apply these guidelines to all job-related situations. It is said that, in a changing society, a code of ethics becomes a living document only after it is applied to the realities of healthcare and must undergo various revisions to meet the current needs [1].

In Japan, the Japanese Nursing Association's Code of Ethics for Nurses (Table 1) specifies the behavioral guidelines for nurses and the scope of responsibility that nurses assume [2]. The 15 articles that constitute the Code of Ethics for Nurses are organized into three sections: Articles 1 - 6, Articles 7 - 11, and Articles 12 - 15. Articles $1-6$ relate to the ethical values and duties that a nurse should observe when providing care. Articles $7-11$ relate to the importance of "effort" on the part of nurses in practice. Lastly, Articles 12 - 15 relate to the

Table 1. Nurses' code of ethics-Japanese nursing association (2003).

Article on the ethical values and obligations that nurses should protect while providing nursing care

1) Nurses shall respect all human lives and the dignity and rights of all human beings.

2) Regardless of nationality, race, ethnicity, religion, creed, age, sex, sexual orientation, social status, economic status, lifestyle, and the nature of their health problems, nurses shall equally provide nursing care to their patients.

3) Nurses should do their best to establish a trustworthy relationship with their patients and to provide nursing based on that relationship.

4) Nurses must respect the patient's right to know, and to make self-determinations and defend those rights.

5) Nurses must strictly adhere to their obligations regarding confidentiality and the protection of personal information, and if they share such information with others, it must be after making the proper judgment to do so.

6) Nurses need to protect their patients and secure their safety, including when caring for these people is being hindered or they are in dangerous situations.

Article on the efforts of nursing staff important for practice

7) Nurses should be well aware of their responsibilities and abilities as they provide care as individuals.

8) It is a nurse's responsibility to always try to maintain and develop his/her abilities through continual learning.

9) Nurses should cooperate with other nurses and other health and medical welfare workers to provide nursing care.

10) To perform the highest quality nursing care, nurses should set and implement helpful criteria for nursing practice, nursing management, nursing education, and nursing research.

11) Through research and practice, nurses always strive to create and develop specialized knowledge and techniques and contribute to the development of nursing science.

Article on basic personal virtues and organizational effort

12) Nurses must try to maintain and improve their own physical and mental health to perform the highest quality nursing care.

13) Nurses must always conduct themselves as individuals worthy of the trust of society.

14) Nurses share responsibility with society regarding environmental issues to promote overall better health.

15) Through professional organizations, nurses should be involved in the establishment of institutions to enhance the quality of nursing care and contribute to the creation of a better society. 
foundations of personal moral consciousness and organizational effort. To respond to ethical problems, the Code of Ethics for Nurses recommends that students learn all aspects from the time of basic nursing education. However, the capacity to make ethical competence during continuous nursing education corresponds to Article 1 through 11 of the Code of Ethics from the Japanese Nursing Association but no reports on Articles 12 to 15. And the competencies acquired included cognizance, judgment, and action [3]. It is thus necessary to synthesize nursing ethics education into basic nursing education so that nurses can understand the Code of Ethics for Nurses and apply the code in decisions concerning judgement and conduct.

For basic nursing education in Japan, five competency areas that comprise nursing practice are outlined in the "Core Practical Competencies for Nursing Practice during the Bachelor Program and Objectives to be Accomplished by Graduation [4]." "Section 1: Practical competencies related to the basics of human care," specifies competencies related to ethics, including "the ability to protect the dignity and rights of those receiving care," and "the ability to explain the treatment being given and obtain consent." The necessity for nursing ethics education to be covered in basic nursing education in Japan is thus specified; however, the required ethical competencies are described abstractly, and concrete educational contents and methods are entrusted to each educational institution or facility. Consequently, nursing educators cannot determine the thought processes that lead students to ethical conduct and are thus left to assess students' ethical conduct amidst lingering ambiguities. Furthermore, students cannot receive ethical training in a timely manner and thus feel a need to further develop their own level of ethical conduct.

By providing an overview of previous research related to ethics education in basic nursing education, this study outlines the ethical competencies acquired through basic nursing education and the present state of ethics education and its challenges. Finally, future directions for ethics education are explored.

\section{Definition of Terms}

\section{1) Ethical Competence}

Ethical competence is based on the framework of Articles 1 - 15 of the Code of Ethics for Nurses [2]. "Cognizance" refers to the ability to recognize feelings of ethical unease in everyday nursing practice, based on knowledge of the ethical standards and concepts necessary for ethical conduct. "Judgement" refers to the ability to collect information related to the feeling of unease, identify the ethical problem, and devise a plan of conduct. "Conduct" refers to the ability to address the ethical problem by providing care while protecting the worth and responsibility of the patient.

\section{2) Basic Nursing Education}

Basic nursing education refers to the education mandated by the Minister of Education, Culture, Sports, Science and Technology or the Minister of Health, 
Labour and Welfare at an educational institution for public health nurses, midwives, or registered nurses prior to becoming licensed in those fields [5].

\section{Method}

\subsection{Literature Search}

The databases used for the research were ICHUSHI, MEDLINE, and CINAHL. The search terms used were "nursing ethics" AND "nursing practice" or "ethics education” AND “nursing students.” Of the total results, 25 research articles (original papers, research reports, practical reports, documents) were used for this study.

\subsection{Analysis Method}

The ethical competencies of nursing students were sorted according to the Code of Ethics for Nurses [2], which forms the basis of nursing conduct policy. The level of ethical competence acquired was evaluated according to cognizance, judgement, and conduct. Next, materials regarding the nursing ethics education covered during basic nursing education were read carefully, and the present state and of nursing ethics education and its challenges were considered. By examining these issues considering research that had already been conducted by scholars specializing in nursing ethics and/or nursing administration, we ensured content reliability and validity.

Concerning ethical considerations, we took care to represent the originals faithfully and to observe copyright when quoting source materials.

\section{Results}

\subsection{Ethical Competence of Nursing Students (Table 2)}

In basic nursing education, ethical competence fell under the following articles of the Code of Ethics for Nurses: Article 1, "respect human life and dignity;" Article 2, "provide nursing care to all people equally;" Article 3, "provide care based on a trusting relationship;" Article 4, "respect the rights of people to information and self-determination;" Article 5, "protect personal information;" Article 6, "protect and safeguard clients;" Article 7, "take responsibility for care provided;" Article 8, "maintain and develop competence as a matter of personal responsibility;" Article 9, "collaborate with other nurses and personnel;" Article 10, "determine standards for nursing practice, management, education, and research;" and Article 11, "contribute to the progress of nursing science through research and practice." However, no scholarly articles were found that related to Article 12, "protect and promote [nurses' own] physical and mental health;" Article 13, "maintain high standards of personal conduct;" Article 14, "share with society the responsibility for environmental issues;" or Article 15, "participate in establishing a system of quality nursing care and contribute to the development of a better society." 
Table 2. Levels of ethical competence acquired in basic nursing education.

\begin{tabular}{|c|c|c|}
\hline Code of Ethics & Publications & Level \\
\hline \multirow{3}{*}{ Article 1} & $\begin{array}{l}\text { Students believed that it is critical to respect the patient even when } \\
\text { there are difficulties reaching a mutual understanding [6] [7] [8]. }\end{array}$ & Cognizance \\
\hline & $\begin{array}{l}\text { Students felt that their own responses during practical training did not } \\
\text { adequately respect the dignity of the patient [9]. }\end{array}$ & Cognizance \\
\hline & $\begin{array}{l}\text { Students felt a dilemma between the dignity of life and quality of life of } \\
\text { the patient }[10] .\end{array}$ & Cognizance \\
\hline Article 2 & $\begin{array}{l}\text { Students thought that giving handmade gifts to sick children during } \\
\text { their pediatric nursing practicum would be a form of favoritism to } \\
\text { specific children, and they worried whether this would be considered } \\
\text { equal provision of care [9]. }\end{array}$ & Cognizance \\
\hline Article 3 & $\begin{array}{l}\text { Since it was not possible to listen to patients' concerns until patients } \\
\text { felt satisfied, students budgeted time into the practicum plan of each } \\
\text { day to spend enough time communicating with patients, thereby } \\
\text { including the formation of a trusting relationship into their plan [8]. }\end{array}$ & Judgement \\
\hline Article 4 & $\begin{array}{l}\text { In cases where the patients cannot be asked, a decision is made as to } \\
\text { how to proceed after consulting with patients' families [8]. }\end{array}$ & Judgement \\
\hline \multirow{2}{*}{ Article 5} & $\begin{array}{l}\text { Students recognized the necessity to protect patients' information and } \\
\text { records [11]. }\end{array}$ & Cognizance \\
\hline & $\begin{array}{l}\text { South African students had a strong desire to protect the } \\
\text { confidentiality of patients with human immunodeficiency virus [12]. }\end{array}$ & Cognizance \\
\hline \multirow{2}{*}{ Article 6} & $\begin{array}{l}\text { Students felt an ethical dilemma about restraining children during } \\
\text { treatment [6] [14]. }\end{array}$ & Cognizance \\
\hline & $\begin{array}{l}\text { In a case study, students judged from the perspective of protecting the } \\
\text { patient from infection to avoid harm [13]. }\end{array}$ & Judgement \\
\hline Article 7 & $\begin{array}{l}\text { Students were cognizant of the need to take responsibility for care } \\
\text { provided in their roles as nurses [8]. } \\
\text { Since students were self-aware about their own responsibilities and } \\
\text { capacities as students, they felt flustered when patients' family } \\
\text { members had higher expectations than the students felt they could } \\
\text { provide [9]. }\end{array}$ & Cognizance \\
\hline Article 8 & $\begin{array}{l}\text { Students were concerned about ethics and wanted to make efforts in } \\
\text { this area going forward [16]. }\end{array}$ & Cognizance \\
\hline Article 9 & $\begin{array}{l}\text { Amid the varying opinions held by medical staff, students thought that } \\
\text { it was problematic that colleagues were not collaborating on how to } \\
\text { best care for patients [6]. }\end{array}$ & Cognizance \\
\hline Article 10 & $\begin{array}{l}\text { Students experienced the lack of a role model to strive for as a dilemma } \\
\text { [15]. }\end{array}$ & Cognizance \\
\hline Article 11 & $\begin{array}{l}\text { Students learned that through efforts by nurses and organizations, } \\
\text { medical care based on respect can be put into practice [16]. }\end{array}$ & Cognizance \\
\hline
\end{tabular}

The largest number of publications related to Article $1(n=6)$. Students felt that it was vital to respect patients by reaching out to them even when there were difficulties arriving at a mutual understanding [6] [7] [8]. Consequently, students sometimes worried that their own responses during practical training did not adequately respect the dignity of the patient, or they felt a dilemma between respecting the dignity of life and patients' quality of life [9] [10]. The next most numerous publications were those related to Articles 5 and 6. For Article 5, which relates to the duty to maintain patient confidentiality, students recognized 
the necessity to take appropriate actions to protect patient information and medical records [11]. It was also reported that the desire to protect patients' confidentiality regarding human immunodeficiency virus was much higher for students in South Africa than it was in the United States [12].

For Article 6, which relates to the duty to protect and safeguard patients, in one case, where a patient wanted to see his/her child at a time when his/her immunity was low, the student thought that the visit should be avoided because it could harm the patient and thus judged from the perspective of protecting the patient from infection [13]. It was also reported that students felt ethical dilemmas about restraining children during treatment [6] [14]. For Article 10, which relates to the setting of desirable standards for nursing practice, students cited the lack of appropriate role models as the most common problem they face, and they experienced this lack of a model to strive for as a dilemma [15]. For Article 8 , which regards the maintenance and development of competence by continuous learning, students' awareness of nursing ethics was raised through ethics education, and they expressed a desire to move forward while maintaining their concern for ethics [16]. These acquired ethical competencies corresponded to the levels of "cognizance" and "judgement."

\subsection{The Present State of Ethics Education in Basic Nursing Education}

There are many case studies of nursing ethics education in Japan, and it has been reported that students can deepen their understanding of the rights and dignity of the patient through group work [17] [18]. This understanding led to an increase in ethical awareness and motivation [19]. Regarding the nursing ethics education covered in each school year, the objective for first-year students was to gain motivation concerning nursing ethics by performing case studies. As an effect of the training, students with no practical experience could raise their awareness of nursing ethics by applying a case where an ethical situation could be imagined [19].

For second-year students, case studies were provided through lectures, also with the aim of raising students' ethical sensitivity. Reports showed that the training gave students the opportunity to think about and recognize ethical problems [6], and to consider the rights and dignity of a child by imagining a sick child [17]. In addition, during practical training, discussing a clinical incident at a conference became an opportunity to share information, discuss preventative measures, reflect on conduct, and think about patient safety [20].

For third-year students, in a course on pediatric nursing, group work was conducted for students to learn how to relate to children while protecting their rights. Because of the training, students could imagine the anxiety that children may experience regarding their care, tests, and treatment; and thereby try to relate to their feelings and think about the rights and dignity of the child [17].

In addition to the teaching methods in nursing ethics education in Japan mentioned above, such as lectures, case studies, and group work, in keeping with 
changes in medical environments and global developments, nurses are also adopting simulation trainings to respond to new ethical problems [21]. These various educational methods have been conducted with the aim of improving ethical competence concerning cognizance and judgement.

In nursing ethics education abroad, joint conferences, blended learning [22] [23] [24], problem-solving training [25], and peer tutoring [26] have been used for students to work through ethical issues together. Furthermore, with the aim of improving the cognizance aspect of ethical competence, education related to concepts, such as ethical principles, ethical problems in healthcare, and codes of ethics were conducted through lectures, discussions, case studies, group discussions, and demonstrations [27]. Analyzing case studies by means of ethical principles also led to an improvement in decision-making abilities [28]. With the aim of improving the judgement aspect of ethical competence, education in solving ethical problems was also conducted by making use of ethical decision-making models (such as the revised 4-step model), blended learning [29], and active simulations using role playing, wherein students could come up with solutions and grasp the reasons for them [29] [30].

\section{Discussion}

\subsection{The Present State of Ethical Competence}

It is necessary for students to gain competence with the entire Code of Ethics for Nurses during their basic education. However, while the present study showed that Articles 1 - 11 of the Code of Ethics for Nurses had been covered exhaustively, no articles were found that referred to the foundational issues of individual moral consciousness and organizational effort. One reason for this may be the difficulty in teaching individual moral consciousness. Nurses perform their duties through a complex negotiation of their own individual moral consciousness and the values sought by their profession through the Code of Ethics. Since individual differences are a matter of personal identity, there is a risk that educational interventions that seek to make rectifications may go against a person's individual character. Teaching in this area can therefore pose difficulties. Another reason is that many nursing students may feel that organizational efforts, such as establishing a system for quality nursing care, is the job of those in management positions. However, managing care as an organization and managing the environment through the systems and policies of a specialized profession include elements of nursing management. Therefore, competencies in these areas should be achieved not only by management, but by students as well.

Regarding ethical competencies, articles were found concerning cognizance and judgement, but not conduct. In the "Model Core Curriculum for Nursing Education" the aim of basic nursing education is for students to learn about ways of thinking, ethical theory and principles, the importance of ethics in nursing practice, and ethical competence at the level of judgement [31]. It is therefore vital to foster critical thinking skills such that students can solve the 
ethical problems that they face in case studies and on-site training, and for students to master the judgement skills necessary to respond to ethical problems in a variety of situations.

\subsection{Ethics Education for the Acquisition of Ethical Competence}

Educators believe that, at present, education aimed at the development of judgment competence, starting in basic nursing education, has not been linked to the acquisition of judgment competence. Davis [32] suggested that teaching critical thinking through lectures has limits and that dialogue and discussion are also necessary, and simulations and blended learning have also been adopted in countries abroad [22] [23] [24]. For nurses to respond to increasingly complex ethical problems, it is necessary to consider how to deliver an ethics education that trains students to respond to ethical problems that are more in tune with current realities, using educational methods beyond only the lectures and case studies that have been employed thus far.

Furthermore, ethical competence in judgement acquired in basic nursing education should be used to respond to increasingly complex ethical problems in continuing nursing education; therefore, it is necessary for a nursing ethics education program to be established that is suitable for each stage of basic nursing education through continuing nursing education, aimed at the acquisition of competence at the level of conduct.

\section{Conclusions}

The ethical competence observed in basic nursing education fell under Articles 1 - 11 of The Code of Ethics for Nurses. However, no scholarly articles were found that related to Articles 12 - 15. Furthermore, the levels of ethical competence acquired corresponded to cognizance and judgment but not to conduct. A future challenge for nursing ethics education will be for a nursing ethics education program to be established that comprehensively covers the Code of Ethics. It is necessary for students to learn The Code of Ethics from the time of basic nursing education. Since Articles 12 - 15 relate to individual moral consciousness, this may be difficult to teach. Furthermore, many nursing students and nurses see organizational efforts, such as the establishment of a system for quality nursing care, as the duty of those in management. This suggests that it is necessary to establish a nursing ethics educational program that comprehensively covers the Code of Ethics starting in basic nursing education.

Moreover, no articles were found regarding ethical competence at the level of conduct in basic nursing education. According to the Model Core Curriculum for Nursing Education [31], students should acquire ethical competence at the level of judgement in basic nursing education; at this stage, it is critical for students to acquire the judgement skills to respond to ethical problems in a variety of situations. However, considering issues of continuity between basic nursing education and continuing nursing education, it may also be necessary for stu- 
dents to gain experience at the level of conduct during basic nursing education.

The issue of ethics education in basic nursing education is the urgent need of education to acquire the judgment level of the student's ethical competence, and the education considering the issue of continuity between basic nursing education and continuing nursing education.

\section{Acknowledgements}

This study forms a part of the research conducted with the support of Grants-inAid for Scientific Research (Basic Research C, General; No. 17K12134). A portion of this paper was presented at the 37th conference of the Japan Academy of Nursing Science. The authors declare that they have no competing interests.

\section{Conflicts of Interest}

The authors declare no conflicts of interest regarding the publication of this paper.

\section{References}

[1] International Council of Nurses (2012) The ICN Code of Ethics for Nurses. https://www.icn.ch/sites/default/files/inline-files/2012_ICN_Codeofethicsfornurses =\%20eng.pdf

[2] Japanese Nursing Association (2003) The Code of Ethics for Nurses. https://www.nurse.or,jp/home/publication/pdf/rinri/code_of_ethics.pdf

[3] Yoshioka, E. and Kaneko, S. (2019) The Current Status of Ethical Judgment Capacity and Ethical Training Regarding Continuous Nursing Education. International of Journal of Nursing \& Clinical Practices, 6, 305. https://doi.org/10.15344/2394-4978/2019/305

[4] Ministry of Education, Culture, Sports, Science and Technology (2011) Core Practical Competencies for Nursing Practice during the Bachelor Program and Objectives to Be Accomplished by Graduation.

http://www.mext.go.jp/b_menu/shingi/chousa/koutou/47/siryo/_icsFiles/afieldfile/ 2011/11/04/1312488_5.pdf

[5] Ministry of Health, Labour and Welfare (2007) Conference Report on Elements of a Complete Basic Nursing Education. https://www.mhlw.go.jp/shingi/2007/04/dl/s0420-13.pdf

[6] Namba, N. (2016) Student Learning through Group Discussion of Ethical Case Studies in Pediatric Nursing. Tokyo Medical University School of Nursing Bulletin, 25, 35-44.

[7] Konno, H. (2012) The Implementation of Ethics Education to Ensure Yhe Dignity of Bedridden Patients and Elderly Patients with Severe Dementia. Tōhoku Bunka Gakuen University School of Nursing Bulletin, 1, 25-33.

[8] Ohata, M. and Hara, S. (2007) Students' Ethical Dilemmas during Practical Training for Geriatric Nursing. Shimane University Faculty of Medicine Bulletin, 30, 1-9.

[9] Miyazato, T., Ohkawa, M., Kakazu, I., et al. (2016) Students' Experiences with Nursing Ethics on Site. Okinawa Prefectural College of Nursing Bulletin, 17, 79-87.

[10] Shiomi, K., Isomoto, A., Tsugeno, H., et al. (2011) Nursing Students' Understanding of Gastrostomy: Recognition of Ethical Aspects According to Experience, and Fu- 
ture Educational Challenges. International Nursing Care Research, 10, 89-98.

[11] Er, R.A., Ersoy, N. and Celik, S. (2014) The Nursing Students' Views about the Patient's Rights at the West Black Sea Universities in Turkey. Nursing and Midwifery Studies, 3, e19136. https://doi.org/10.17795/nmsjournal19136

[12] Relf, M.V., Laverriere, K. and Devlin, C. and Salerno, T. (2009) Ethical Beliefs Related to HIV and AIDS among Nursing Students in South Africa and the United Stated: A Cross-Sectional Analysis. International Journal of Nursing Studies, 46, 1448-1456. https://doi.org/10.1016/j.ijnurstu.2009.05.001

[13] Yoshimoto, N. and Yatsushiro, R. (2011) What First Year Students at Nursing Colleges Feel to Be the Grounds for Their Ethical Judgments. Japan Nursing Ethics Association Newsletter, 3, 58-63.

[14] Tachibana, N., Miyagi, Y. and Yoshikawa, M. (2011) Caregiving Methods that Nursing Students Learned in Pediatric Nursing Practicum to Respect the Rights of the Child. Fukuoka Prefectural University Nursing Science Research Bulletin, 8, 19-25.

[15] Yeh, M.Y., Wu, S.M. and Che, H.L. (2010) Cultural and Hierarchical Influences: Ethical Issues Faced by Taiwanese Nursing Students. Medical Education, 44, 475-484. https://doi.org/10.1111/j.1365-2923.2009.03589.x

[16] Kitamura, S. and Sekiya, Y. (2016) A Consideration of the Ethics Education Program at Red Cross Nursing Schools: An Analysis of Nursing Students' Self-Assessment of the Learning Objectives in a Nursing Ethics Course, and Their Reactions to the Course. Japanese Red Cross Society of Nursing Science Journal, 16, 25-31.

[17] Shimada, M., Murakami, H. and Nishikawa, Y. (2014) A Study of Teaching Activities for Ethics Education in Pediatric Nursing. Kanagawa Rehabilitation Center Atsugi Nursing School Bulletin, 4, 29-32.

[18] Yamakawa, Y., Morimoto, T., Sato, M., et al. (2010) The Ethics Education Project at this School and Its Outcomes: Was the Ethics Education Project Useful for Students to Advance Their Sense of Ethics? Osaka Medical College Faculty of Nursing Bulletin, 16, 33-41.

[19] Yoshikawa, Y., Shiba, M. and Tawara, K. (2010) Assessment of Nursing Ethics Education during Basic Nursing Education Using Case Studies. International Nursing Care Research, 99, 83-89.

[20] Oshita, M., Miyazono, M., Murase, K., et al. (2005) An Experiment in Raising Ethical Sensitivity: Student Learning at a Conference Regarding Incident Reports. Kyushu Welfare Pension School of Nursing Bulletin, 6, 61-76.

[21] Wonder, A.H. (2016) Mock Hospital Ethics Committee: An Innovative Simulation to Teach Pre-Licensure Nursing Students the Complexities of Ethics in Practice. Nursing Education, 42, 77-80. https://doi.org/10.1097/NNE.0000000000000320

[22] Hsu, L.L. (2011) Blended Learning in Ethics Education: A Survey of Nursing Students. Nursing Ethics, 18, 418-430. https://doi.org/10.1177/0969733011398097

[23] Hsu, L.L. (2012) Qualitative Assessment of a Blended Learning Intervention in an Undergraduate Nursing Course. Journal of Nursing Research, 20, 291-299. https://doi.org/10.1097/jnr.0b013e31827363bc

[24] Hsu, L.L. and Hsieh, S.I. (2011) Effects of a Blended Learning Module on Self-Reported Learning Performances in Baccalaureate Nursing Students. Nursing Ethics, 67, 2435-2444. https://doi.org/10.1111/j.1365-2648.2011.05684.x

[25] Khatiban, M., Falahan, S.N., Amini, R., Farahanchi, A. and Soltanian, A. (2018) Lecture-Based versus Problem-Based Learning in Ethics Education among Nursing 
Students. Nursing Ethics. https://doi.org/10.1177/0969733018767246

[26] Lin, C.F., Lu, M.S., Chung, C.C. and Yang, C.M. (2010) A Comparison of Problem-Based Learning and Conventional Teaching in Nursing Ethics Education. Nursing Ethics, 17, 373-382. https://doi.org/10.1177/0969733009355380

[27] Görgülü, R.S. and Dinç, L. (2007) Ethics in Turkish Nursing Education Programs. Nursing Ethics, 14, 741-752. https://doi.org/10.1177/0969733007082114

[28] Dinç, L. and Görgülü, R.S. (2002) Teaching Ethics in Nursing. Nursing Ethics, 9, 259-268. https://doi.org/10.1177/096973300200900305

[29] Cameron, M.E., Schaffer, M. and Park, H.A. (2001) Nursing Students' Experience of Ethical Problems and Use of Ethical Decision-Making Models. Nursing Ethics, 8, 432-437. https://doi.org/10.1191/096973301680195364

[30] Gropelli, T.M. (2014) Using Active Simulation to Enhance Learning of Nursing Ethics. The Journal of Continuing Education in Nursing, 41, 104-105. https://doi.org/10.3928/00220124-20100224-09

[31] Ministry of Education, Culture, Sports, Science and Technology (2017) Model Core Curriculum for Medical Education.

http://www.mext.go.jp/component/a_menu/education/detail/_icsFiles/afieldfile/20 17/10/31/1217788_3.pdf

[32] Davis, A.J. and Konishi, E. (2008) Nursing Ethics: The Perspective and Method of Learning Ethics Education. Chapter 18, Japanese Nursing Association Publishing, Tokyo. 